\title{
GUIDED IMAGERY USING CLASSICAL MUSIC ON THE REDUCTION IN PAIN LEVEL OF FRACTURE PATIENTS
}

\author{
Candra Kusuma Negara ${ }^{1 *}$, Achmad Murjani ${ }^{2}$, Anna Martiana ${ }^{3}$, Fajar Kurniawan ${ }^{4}$ \\ ${ }_{1,2,3,4}$ Institute Of Health Science Cahaya Bangsa Banajrmasin \\ Email*: Candra14780@yahoo.com
}

\begin{abstract}
Introduction: Fracture is the medical term for a broken bone. Fractures are common; the average person has two during a lifetime. One of the Intervention on handling the case of fracture is surgical operation. Method of handling the pain that can be done is the non-pharmacological techniques that provide guided imagery through the use of classical music. The purpose of this study to understand the effect of guided imagery utilizing classical music to decrease the scale of pain on post fracture surgery. Methods: The study was quasi-experimental pre-test and posttest group approach The sampling technique employed was accidental sampling with the total of 22 respondents. The guided therapy image uses classical music with an intensity of 60-80 dB and a volume of 40-50\% for +/- 20 minutes. The data collection tool utilized was VAS (Visual Analog Scale) observation sheets. The data analysis utilized was Wilcoxon Sign Rank Test. Results: The result of statistical analysis of Wilcoxon Signed Rank Test obtained p value $=0.000$ with significance level $<0.05$, it was found that there was an effect of giving classical music therapy to a decrease in the pain scale of post-fracture patients. Musical intervention was associated with a significant decrease in heart rate, improvement in oxygen saturation, and reduction in the perception of paint. Conclusions: There was an influence upon the use of guided imagery utilizing classical music towards the decreasing scale of pain on post fracture surgery.
\end{abstract}

Keywords: classical music; guided imagery; pain.

\section{INTRODUCTION}

Fractures are potential and actual threats to a person's integrity, so they will experience physiological and psychological disorders that can cause a response in the form of pain (Mediarti, 2015). Fracture is a condition in which the system of continuity of bone and / or cartilage is completely or partially caused by involuntary or osteoporosis (AAOS, 2013) The World Health Organization (WHO, 2011) noted that in 2011-2012 there were 5.6 million people died and 1.3 million people suffer fractures due to traffic accidents. Fractures that occur can cause common symptoms, namely pain or pain, swelling and deformity. Pain is a feeling that is uncomfortable and subjective where only patients can feel it. For this reason, it is necessary to find the most effective approach in an effort to control pain (Potter, 2006).

One of the biggest fears of fracture patients is pain, for that nurses need to provide information to patients and families of patients about non-pharmacological therapies that can help patients eliminate or reduce pain including music therapy. Music can touch individuals both physically, psychosocial, and spiritually (Campbell, 2006).

Music has been shown to show effects, namely lowering blood pressure, and changing the perception of time. Nurses can use music creatively in various clinical situations, patients generally prefer to do an activity playing a musical instrument, singing a song or listening to music, is the best choice (Potter, 2006). Music produces changes in the status of consciousness through sound, silence, space, and time. Music must be listened to at least 15 minutes so that it can provide a therapeutic effect. In the state of acute care, listening to music can provide very effective results in an effort to reduce the patient's postoperative pain (Potter, 2006). McCaffrey's study found that pain intensity decreased by $33 \%$ after music therapy by using Mozart's classical music on osteoarthritis patients for 20 minutes with Mozart's music (Chiang, 2012). According to research from Draxel University classical music has a low resonance so it has slow music that can be easily accepted in the sense of hearing which is then forwarded to the brain which can stimulate the hormone relaxation.

Based on the results of interviews with 6 patients in the Hospital, researchers found that 1 
patient had pain with 7 pain scales (severe pain scale), 3 patients experienced pain on a scale of 4 - 6 (moderate). pain scale), and 2 patients experienced pain on a scale of 1-3 (mild pain scale).

Nursing interventions in the hospitals are not only based on pharmacological treatment but overall and comprehensive nursing interventions. the expected solution of this study is nonpharmacological therapy to reduce pain, especially in fracture patients.

Nursing interventions in the hospitals are not only based on pharmacological medication but nursing interventions as a whole and comprehensive. the solution expected from this research is non-pharmacological therapy to reduce pain especially in fracture patients. The purpose of this study to understand the effect of guided imagery utilizing classical music to decrease the scale of pain on post fracture surgery.

\section{METHODS}

This research was quantitative research, using quasi-experiment method with pretest approach and post-test group design. Sampling technique in this research is Non Probability Sampling; Accidental Sampling. So in taking the sample the researcher chose the available patients who had fracture surgery and experienced pain in the hospital. Processing data in this study uses the following stages, namely editing, coding, data entry cleaning and tabulating.

Respondents in this study were patients post fracture surgery in the Hospital, with the inclusion criteria as follows : Patients post fracture surgery, Patients who are willing to do therapy, Patients aged $\geq 12$ years, Patients who have entered the 2nd day after fracture surgery, All patients have fractures except for cranii base fracture, because in this fracture the patient is unconscious, Adjust the Medical Record data (RM) and Notes, Patient's Drug Development (CPO), Patients who can be given therapy are 12 hours of half-life, The medicine is almost finished, Adjust the influence of analgesic drugs and antibiotics, Patients who do not experience communication disorder, Patients who have no hearing loss, Patients who have not been affected by the analgesic effect.
The exclusion criteria for this study are: In patients who experience agitation / anxiety, and fear, The patient shows discomfort when given therapy guided imagery using classical music.

The research was held on 07 May - June 7 2018. However, if around one month the researcher could not finish of getting the data (with 22 of minimum sample as sufficient samples) then the researcher will make longer the time of the research until the sufficient data needed is gotten. The instruments used in this research are SOP Guided Imagery, media player, earphone, music recording of classic Mozart, an observation sheet of pain scale measurement Visual Analog Scale (VAS), and wrist watch. Statistical test used in this research is the Wilcoxon Signed Rank Test with 95\% significance level $(p=0.05)$. The pain VAS is a dimensional measure of pain intensity, which has been widely used in diverse adult populations, including those with diseases.

Research procedure: The researcher determined the respondents based on the specified inclusion criteria. The researcher will provide an explanation to the respondent regarding the purpose, objectives, benefits and methods of research management. If the respondent is willing to be a research sample, ask the respondent to approve the consent sheet to be the research respondent. The researcher will conduct pain assessment for 5 minutes before doing therapy (guided images using classical music). The guided therapy image uses classical music with an intensity of $60-80 \mathrm{~dB}$ and a volume of $40-50 \%$ for 20 minutes.

Using earphones and mp3 with a frequency of 1 time a day for 2 days at the same time. Giving therapy starts 24 hours after fracture surgery. Next the researcher will measure the scale of the respondent after 10 minutes of therapy (posttest). The results of the pain scale measurements (pretest and posttest) were recorded on the observation sheet. Provision of adjustment therapy for Medical Record (RM) data and Medication Development Note (CPO) of patients. Researchers can provide therapy to patients with the following conditions: Analgesic medication, 1-2 hours of resting time the drug inhibits finished: Ketorolac: 2x10 $\mathrm{mg}$ and 
3x30mg \& Antrain: 3x500 mg. Antibiotics, 1-2 hours of collection time is almost complete.

Based on the research ethical feasibility statement No. 342 / II-Reg Research / RSUDU / 19 from the Research Ethics Commission of Ulin Hospital Banjarmasin, this research is ethical.This study has been conducted in hold principle of research ethics like anonymity, autonomy, veracity, beneficence, justice and informed consent also.

\section{RESULTS}

Table.1 Distribution Of Respondent According to Demographic Characteristics

\begin{tabular}{|c|c|c|}
\hline Characteristics & $\begin{array}{c}\text { Frequency } \\
\text { (n) }\end{array}$ & $\begin{array}{c}\text { Percentage } \\
(\%)\end{array}$ \\
\hline \multicolumn{3}{|l|}{ Gender } \\
\hline 1. Man & 14 & 63.6 \\
\hline 2. Woman & 8 & 36.4 \\
\hline Total & 22 & 100 \\
\hline \multicolumn{3}{|l|}{ Age } \\
\hline 1. $17-25$ & 9 & 40.9 \\
\hline 2. $26-35$ & 7 & 31.8 \\
\hline 3. $36-45$ & 3 & 13.6 \\
\hline 4. $46-55$ & 3 & 13.6 \\
\hline Total & 22 & 100 \\
\hline \multicolumn{3}{|l|}{$\begin{array}{l}\text { Experience of } \\
\text { surgery }\end{array}$} \\
\hline $\begin{array}{l}\text { 1. Never had } \\
\text { surgery }\end{array}$ & 3 & 13.6 \\
\hline $\begin{array}{l}\text { experience } \\
\text { 2. } \\
\text { Never had } \\
\text { surgery }\end{array}$ & 19 & 86.4 \\
\hline Total & 22 & 100 \\
\hline \multicolumn{3}{|l|}{ Pain Scale } \\
\hline 1. No Pain & 4 & 18.2 \\
\hline 2. Mild Pain & 9 & 40.9 \\
\hline 3. Moderate & 9 & 40.9 \\
\hline $\begin{array}{ll} & \text { pain } \\
\text { 4. } & \text { Severe pain } \\
\end{array}$ & 0 & 0 \\
\hline Total & 22 & 100 \\
\hline
\end{tabular}

From the table 1, it was found that the highest number of respondents' sex was 14 $(63.6 \%)$, the highest age range was $17-25$ years (40.9\%), had never had previous surgery as many as $19(86.4 \%)$, at the same time with mild pain 9 people $(40.9 \%)$ and moderate pain as many as 9 people $(40.9 \%)$.

Table 2. Effect of Guided Imagery Using Classical Music Against Decreasing Pain Scale Post-Fracture Operations in the hospital.

$\underline{\text { Rank }}$

\begin{tabular}{lllll}
\hline & & N & $\begin{array}{l}\text { Mean } \\
\text { Rank }\end{array}$ & $\begin{array}{l}\text { Sum } \\
\text { Of } \\
\text { Rank }\end{array}$ \\
\hline $\begin{array}{l}\text { Post- } \\
\text { Pretest }\end{array}$ & $\begin{array}{l}\text { Negative } \\
\text { Ranks }\end{array}$ & 15 & 8.00 & 120.00 \\
\cline { 2 - 5 } & $\begin{array}{l}\text { Positive } \\
\text { Rank }\end{array}$ & 0 & 0.00 & 0.00 \\
\cline { 2 - 5 } & Ties & 7 & & \\
\cline { 2 - 4 } & Total & 22 & & \\
\hline
\end{tabular}

Test Statistics

Posttest-Pretest

\begin{tabular}{lcc}
\hline $\mathrm{Z}$ & & -3.873 \\
\hline Asymp.tailed) & Sig. (2-tailed) & 0.000 \\
\hline
\end{tabular}

The results of the Wilcoxon Signed Rank Test statistical test obtained $\mathrm{p}$ value $=0,000$ with a significance level of $<0.05$, this the probability value of 0,000 is smaller than $\alpha=$ 0.005 .

\section{DISCUSSIONS}

The Wilcoxon Signed Rank Test statistical test results $p$ value $=0,000$ This shows that the effect of classical music therapy on scale reduction in fracture patients. This finding align with the research conducted by (Isnanto, 2016) where it proves that there is a difference between giving about relaxation using guided music therapy in reducing the pain of appendicitis patients. Research conducted by (R Djamal, 2015), about the effects of music on the pain scale in post-fracture patients with the positive effects of administering this therapy for pain. Guided imagery in general relaxation techniques such as repair, repair, and help reduce the body from various diseases such as depression, asthma.

Therapy using classical music in patients after fracture surgery is very opposed to relaxation specifically in decreasing pain intensity. Relaxation techniques are to reduce muscle relaxation, especially muscles, and this allows to reduce pain. Some studies proven to prove relaxation techniques can prove pain 
(Smeltzer, 2013). The results of this study are also related to what was done by (Nilson, 2018) about the effect of music therapy on the level of perception in myocardial infarction patients with the results of the study obtained from a greater degree of reduction in the level of intervention in intervention patients. opposed to the level of pain. McCaffery's research found that the intensity of the decline decreased by $33 \%$ after music therapy using Mozart's classical music for osteoarthritis patients for 20 minutes with Mozart's music (Dian, 2012). This is in line with the research conducted by Negara (2017) in his research to find Pain can affect a person's psychological condition, especially his emotional state, so that his emotions are focused on pain conditions that have an impact on the environment around him.

The results of this study were also carried out by research conducted by conducted by Novita (2012) shows there is a therapeutic effect music for postoperative pain ORIF (Open and Internal Reduction) Fixation) in Lampung Province Hospital. In addition, the results of this study as well Supported by the results of research Chiang (2012) shows that effect Natural music and sound therapy can reduce recovery and recovery rates cancer treatment in Taiwan. And research that is Performed by Sari and Adilatri (2012), they stated that classical therapy mozart can reduce the intensity of menstrual pain in young women in high school 5 Denpasar. Types of relaxation and distraction music that can be used as an alternative is mozart classical music, where the music is up to 60 beats per minute. Music that has a tempo between 60 to 80 beats per minute able to make someone who listens to it relax (Sulaminingsih, 2012).

If an individual experiences the same type of pain, it will easier for individuals to take actions for pain relief (Potter and Perry, 2006). This happened because of their presencethe central control process and is influenced by past experience. When there are activities that cause pain stimulation, then togetherhence there is a strong central control of the pain reactionsproduced (Kristiarini and Latifa, 2013).

According to researchers, providing analgesic and music therapy has been shown to provide greater comfort by only being given analgesics in patients with fractures. Can be used as complementary therapy in fracture patients.
Reducing this damage. Side effects from analgesic can also be helpful because there is a link between the provision of music therapy in fractured patients and patients who are recommended for a reduction in the dose of analgesic consumption. This can increase patient satisfaction in nursing services.

Limitation of study: In this study, researchers did not count (Control) There are other factors that can influence scale changes Anxiety can improve the perception of pain and pain can also cause respondents are worried. The environment can also affect changes in the scale of pain respondent. Most respondents are patient care class III, and the others are class I and class II patients. Some respondents refused to be given guided image therapy using classical music with reasons not to believe in the existence of this therapy. There are factors that do not support this research, namely: area of fracture suffered by the respondent.

\section{CONCLUSIONS}

There is an effect of guided imagery using classical music due to the reduction of pain scale for patients after fracture surgery in the Hospital.

\section{SUGGESTIONS}

The results of this research are expected to be a new additional knowledge about pain management for patients after fracture surgery. Further research on the effectiveness of other types of music needs to be examined in depth such as morotal and so on.

\section{REFERENCES}

AAOS. (2013). Distal Radius Fracture (Broken Wrist). America: AAOS.

Campbell, D. (2006). Music : Physician For Times to Come (3 ed.). Wheaton: quest books.

Chiang, L. (2012). The effect of music and nature sounds on cancer pain and anxiety in hospice cancer patients. . (unpublished dissertation paper).

Dian, N. (2012). Pengaruh terapi musik terhadap nyeri post operasi Open Reduction And 
Guided Imagery with Classical Music ... (Candra, et.al)

Internal Fixation (ORIF) di RSUD DR. H.ABDUL MOELOEK PROVINSI $L A M P U N G$.

Isnanto. (2016). Pengaruh Pemberian Relaksasi Guided Imagery Terhadap Nyeri Pada Pasien Pasca Apendiktomi Di RSUD Wirosaban.

Kristiarini, D, dan Latifa. (2013). Pengaruh Teknik Relaksasi Autogenik Terhadap Skala Nyeripada Ibu Post Operasi SC Di RSUD Banyumas. . http://keperawatan.unsoed.ac.id/sites/def ault/files/dwi_skripsi_p57-p75.pdf. Diakses tanggal 4 Juli 2019.

Mardiono. (2010, 11 20). Teknik Distraksi.

Retrieved from (www.qittun.com), accessed February 2, 2019

Mediarti, d. (2015). Pengaruh Pemberian Kompres Dingin Terhadap Nyeri pada Pasien Fraktur Ekstremitas Tertutup di IGD RSMH Palembang. jurnal kedokteran kesehatan, https://ejournal.unsri.ac.id/index.php/jkk /article/view/2826.

Negara, C. K. (2017). POST AMPUTATION RESPONSE AND COPING OF DIABETES MELLITUS PATIENT IN ULIN GENERAL HOSPITAL BANJARMASIN. Jurnal Ilmu Keperawatan, 5(2), 114-129.

Nilson, U. (2018, 11 20). Retrieved from Caring Musik: Musik Intervention For Improved Healt,: ,(www.orebrollcom/se/uso/page _2436.aspx

Notoadmodjo. (2013). Metodologi Penelitian Kesehatan. Jakarta: PT.Rhineka Cipta.

Novita, Dian. (2012) Pengaruh Terapi Musik Terhadap Tingkat Nyeri pada pasien pasca operasi Open Reduction and Internal Fixation (ORIF) di RSUD Dr.
H. Abdul Moeloek Provinsi Lampung. http://lontar.ui.ac.id/file?file=digital/ 20328120-T30673persen20 persen20Pengaruhpersen20terapi.pdf. Tesis tidak diterbitkan. Diakses pada tanggal 23 Januari 2019.

Potter, P. (2006). Fundamental of Nursing : Concepts, Process and Practice (4 ed.). Jakarta: EGC.

R Djamal, R. B. (2015). Pengaruh Terapi Musik terhadap Skala Nyeri Pada Pasien Fraktur Di IRNA RSUP Prof.Dr.R.D. Kandou Manado.

Sari, P. dan Adilatri, S.A.(2012). Perbedaan Terapi Musik Klasik Mozart dengan Terapi Musik Kesukaan Terhadap Intensitas Nyeri Haid Pada Remaja Putri Di SMA Negeri 5 Denpasar Tahun 2012.

Smeltzer, S. C. (2013). Buku Ajar Keperawatan Medikal Bedah Brunner And Suddart. Jakarta: EGC.

Sulaimaningsih. (2012). Perbedaan Nyeri Pada Pasien Pasca Operasi Seksio sesarea pertama dengan Pasien Pasca Operasi Sectio Caesaria Berulang Yang Diberikan Ketorolac $30 \mathrm{Mg}$ di RSUD Ambarawa. http:// 2012. Diakses pada tanggal 2 Februari 2019.

WHO. (2011). Injuries in road traffic accidents. USA. Retrieved from https://www.google.com/search?safe=str ict\&source $=\mathrm{hp} \& \mathrm{ei}=\mathrm{d} 4-$ dXMftMdeVwgPV5KGoBw\&q=WHO $\% 29+$ recorded+in+20112012+there+were+5.6+million+people+ died+and $+1.3+$ million+people + suffer $+\mathrm{fr}$ $o m+$ fractures+due+to+traffic + accidents. $\& b$ tnK $=$ Penelusuran + Google $\&$ oq $=W H$ $\mathrm{O} \% 29+$ record 